\title{
Addressing pit wall instabilities in Africa's largest open pit copper mine
}

\author{
GC More O'Ferrall First Quantum Minerals Ltd, Zambia \\ NS Simbile Kansanshi Mining Plc, Zambia
}

\begin{abstract}
Kansanshi Mine is currently Africa's largest open pit copper mine. Initial slope geometry was determined with limited geotechnical data, assuming dry wall conditions. As the mine developed, the assumptions made for the initial design proved to be rather optimistic. The depth, and degree, of weathering was greater than assumed, and groundwater influence was soon realised. Phyllite is present fairly close to the original surface in some portions of the pit, and the clay content of this material appears to have been overlooked during the design phase. After approximately three to five years of exposure to the climatic conditions, the 'fresh' phyllite has degraded and wall instability in this material type is starting to occur. In addition to this issue, several large fault zones traverse the pit. These zones are deeply weathered, and issues are being experienced due to blast-induced failure of the weathered fault gouge.

The focus of the Geotechnical Engineering team on Kansanshi Mine is on obtaining pertinent geotechnical data to assess the instability risk of the final walls of the pit (the depth is currently approximately $200 \mathrm{~m}$, and one of the final walls comprises the weathered phyllite, with no option to pushback), assessing the presplit blast design to minimise back-break into the wall and the fault zones, and develop a saprolite depressurisation program in an attempt to maintain the stability of the uppermost benches close to the pit crest.

Instabilities experienced and addressed during the development of the pit, remedial actions taken to minimise the risk associated with these occurrences, and findings of the geotechnical data assessments are presented.
\end{abstract}

Keywords: design, instability, depressurisation, presplit, weathering

\section{Introduction}

Kansanshi Mine, the largest copper mine in Africa, is owned and operated by Kansanshi Mining Plc which is $80 \%$ owned by a First Quantum subsidiary. The remaining $20 \%$ is owned by a subsidiary of ZCCM (ZCCM Investments Holdings is a successor company to Zambia Consolidated Copper Mines Limited, of Zambia). The mine is located approximately $10 \mathrm{~km}$ north of the town of Solwezi and $180 \mathrm{~km}$ to the northwest of the Copperbelt town of Chingola. Surface mining operations are conducted from two pits, Main Pit and North West Pit. Main Pit is the larger of the two, with approximate dimensions of 3,200 m long, 1,387 $\mathrm{m}$ wide and with an average depth of $220 \mathrm{~m}$ below surface (mbs). The final planned depth of mining is approximately $400 \mathrm{mbs}$. North West Pit is approximately 2,100 m long, 1,700 m wide and approximately $125 \mathrm{~m}$ deep on average (Figure 1). There is no mineralisation below the current North West Pit footprint. 

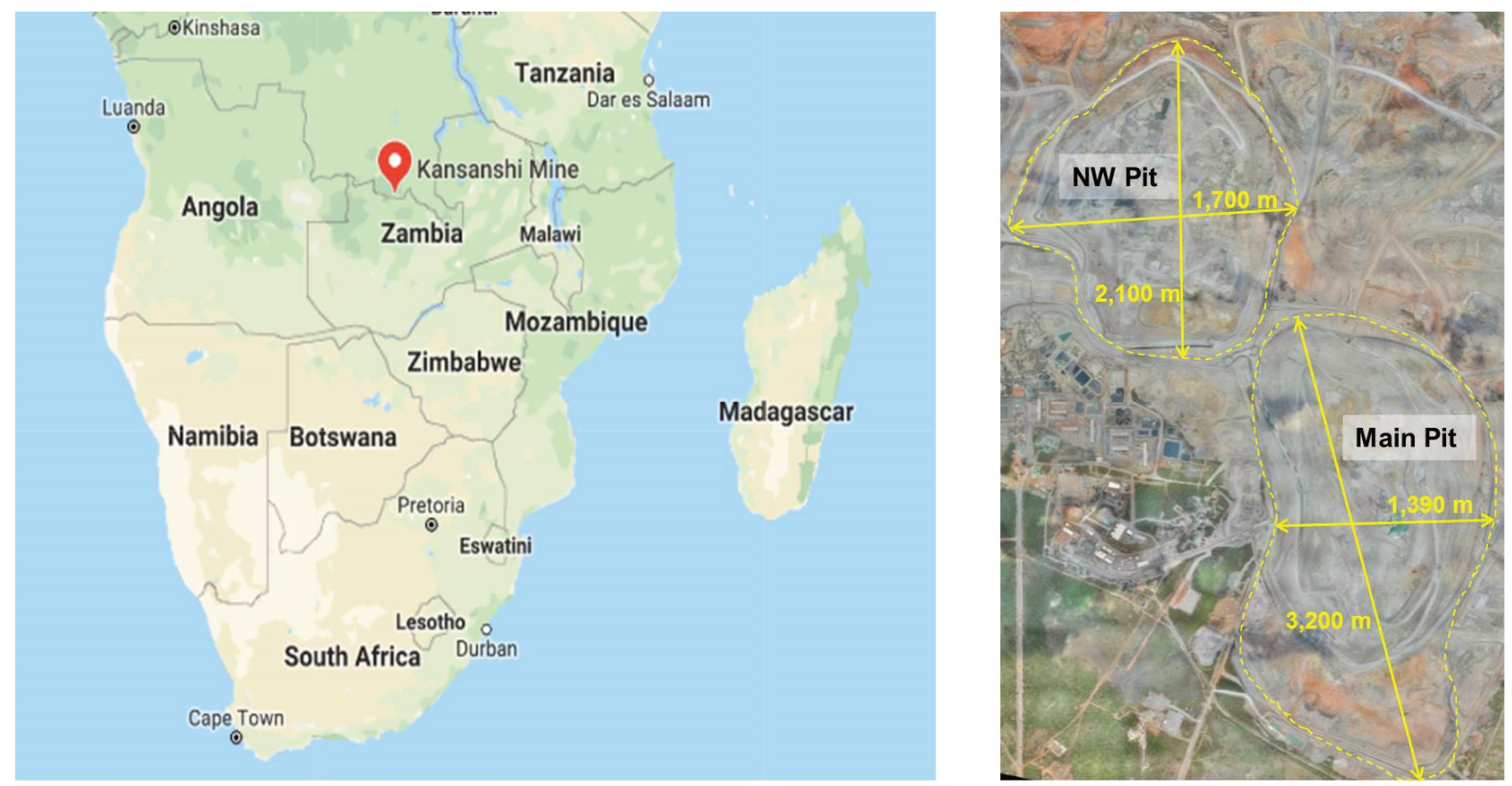

Figure 1 Location of Kansanshi Mine in Northwest Zambia

The mine has undergone several expansions since it began operating in 2005. From an initial production capacity of $110,000 \mathrm{t}$ of copper, Kansanshi is now capable of producing $340,000 \mathrm{t}$ of copper and more than 120,000 ounces of gold per annum.

Historically, mining at Kansanshi Mine site was by underground mining methods. Historical underground workings have been intersected during the surface mining activities (Figure 2), and thus far have not posed any significant risks.

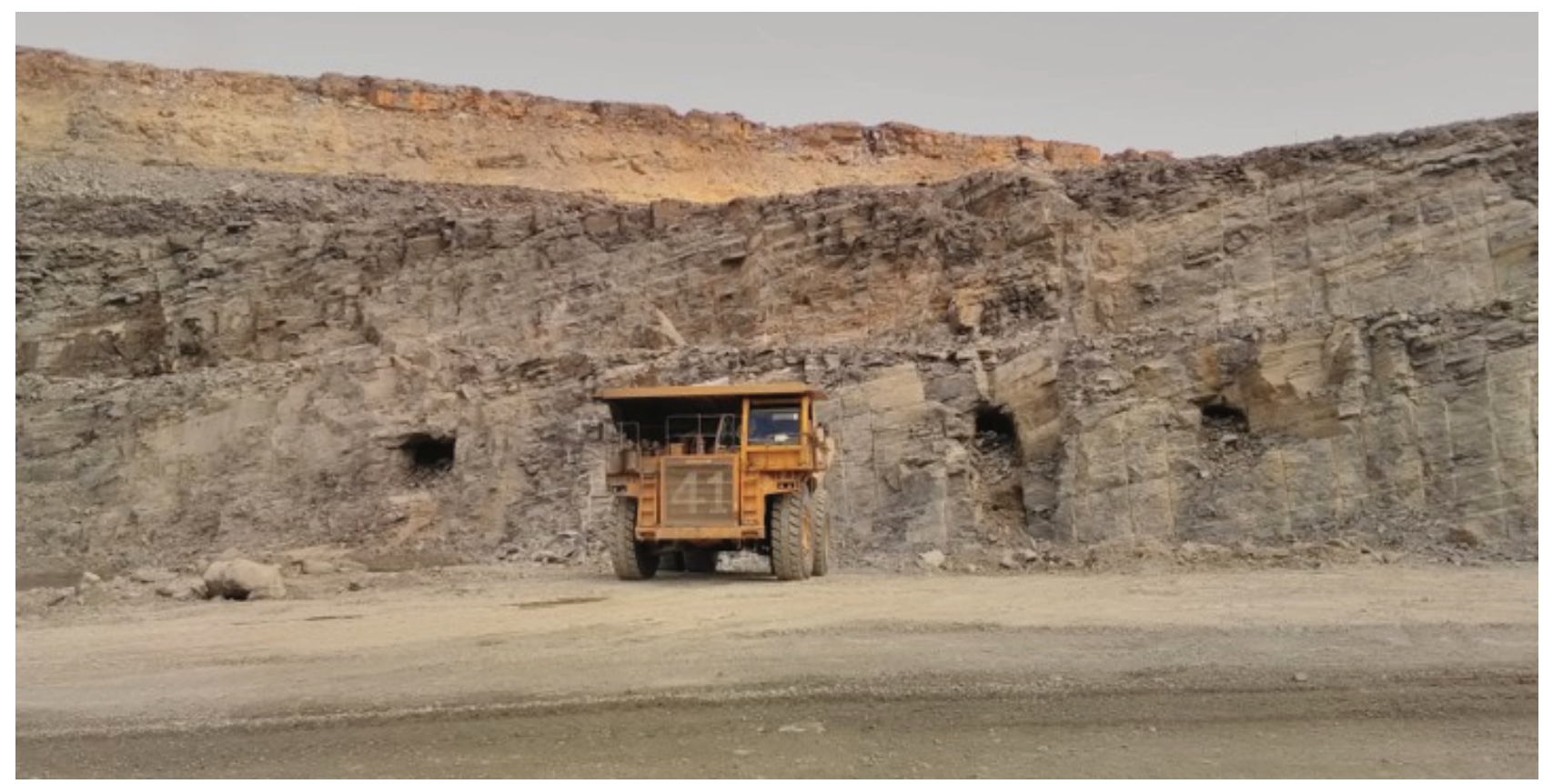

Figure 2 Tunnels intersected during surface mining 


\section{Geologic setting of the Kansanshi deposit}

The Kansanshi deposit, currently mined from Main Pit and North West Pit, is hosted by deformed metasediments of the Lower Kundelungu Group within the Katanga Supergroup of the Zambian Copperbelt. The individual rock units of the stratigraphic sequence comprise dolomites, dolomitic marbles, and various schists and phyllites. The recently defined South East Dome and Rocky Hill deposits, in the southeast of the tenement, are similarly hosted but structurally displaced to a lower elevation due to structural deformation, i.e. folding.

Copper mineralisation at Kansanshi Mine occurs within two domal structures along the crest of a regional antiform. These domes are closely associated with the deposit mineralisation being mined in Main and North West Pits. Three styles of primary sulphide mineralisation are associated with these domes:

1. Stratified and disseminated mineralisation.

2. Sub-vertically dipping, quartz-carbonate-sulphide veins crosscutting the stratigraphy.

3. Breccia mineralisation (localised).

Oxidation of primary mineralisation is associated with depth of weathering, and is reflected as:

- Near surface weathering in the saprolitic zone and in and around vertical veins, with oxide mineralisation predominantly evident as malachite and tenorite.

- Mixed mineralisation, reflecting a wide variety of both primary and secondary copper ore mineralogies, that occurs in a wide transitional zone between the base of complete oxidation and the top of fresh rock.

- Near surface to deep, pervasive weathering along brittle geological structures, predominantly faults and fault zones and their associated synthetic joint sets.

Mineralisation at South East Dome and Rocky Hill is associated with near vertical brecciation and veins as well as slightly lower grade stratigraphic controlled mineralisation. The current framework suggests that elevated accumulations of mineralisation occur in the structurally deformed area between the Main Pit and the South East Dome deposits. This area is essentially defined by an inflection point in an approximately east-west trending regional fold nose resulting from the envelopment of a gabbro mega-clast. The stratified, hypogene component of the mineralisation in the South East Dome Deposit is similar to that observed in both the North West Pit and Main Pit.

Primary copper sulphide mineralisation is dominated by chalcopyrite with minor bornite and is accompanied by relatively minor pyrite and pyrrhotite. Oxide mineralisation is dominated by chrysocolla with malachite, limonite and cupriferous goethite. The mixed zone includes both oxide and primary mineralisation but also carries significant chalcocite, minor native copper and tenorite. Some copper appears to be hosted in clay and mica minerals and is essentially classified as refractory. Gold mineralisation occurs in association with copper.

\section{Slope performance and failure mechanisms in Main Pit}

Figure 3 is an aerial photograph of Main Pit, indicating the location and orientation of the relevant figures used in this paper. Slope stability is being monitored by a geodetic system complemented by two Reutech Movement and Surveying Radars, MSRs, (indicated by the red stars in Figure 3). The long-axis of Main Pit is approximately WNW-ESE, and the pit extension is planned towards the SE. The depth of weathering within the current pit footprint varies from approximately $50 \mathrm{~m}$ to $250 \mathrm{~m}$ below surface topography. 


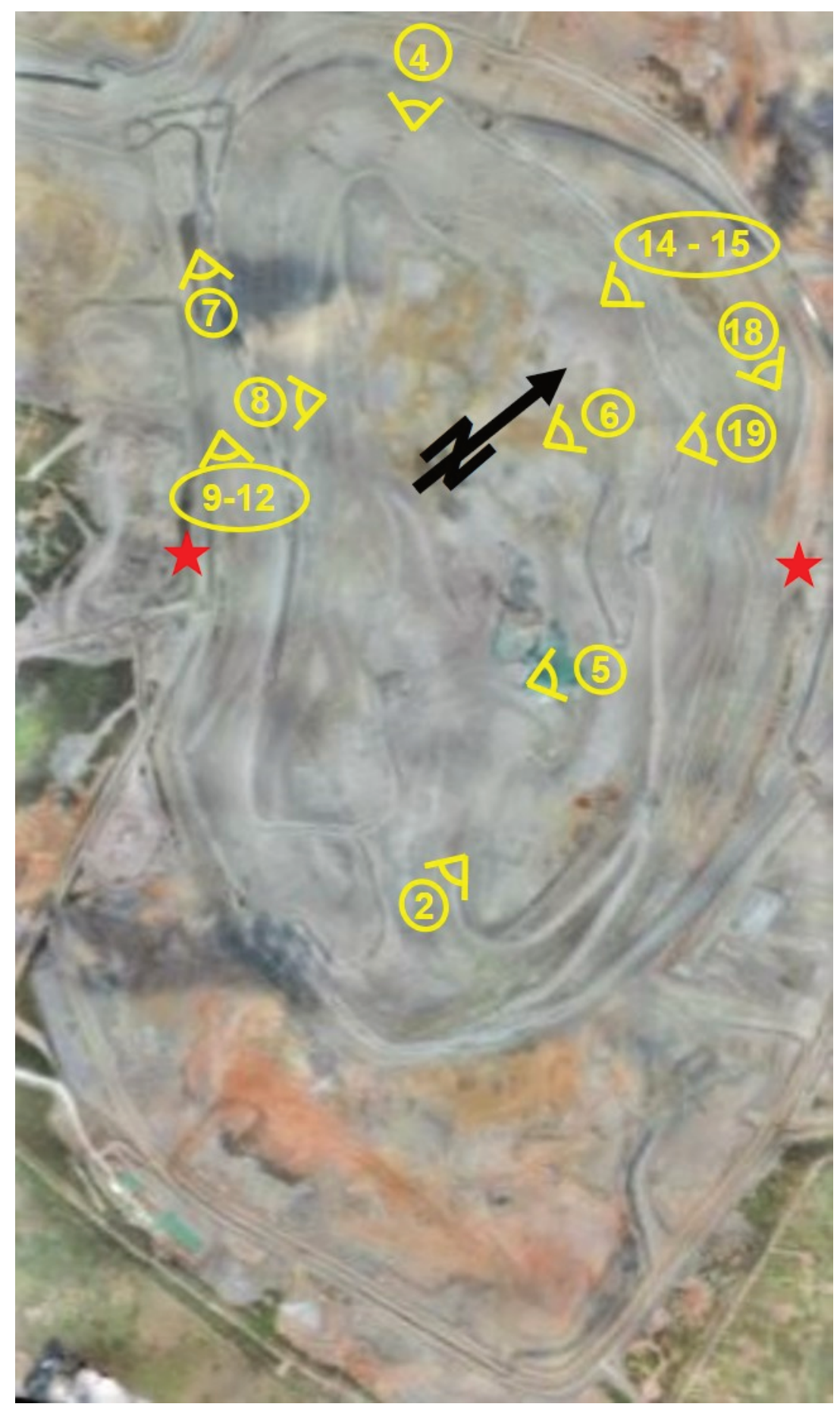

Figure 3 Location and orientation of figures and movement and surveying radars

Failures within the weathered zone vary from erosion channels (Figure 4) due to inadequate surface water management, to larger wedge-type failures associated with geologic structure and pit wall orientation. In the highly-to-moderately weathered zone, pit wall configuration comprises $5 \mathrm{~m}$ bench heights with $5 \mathrm{~m}$ wide catch berms and bench face angles of $65^{\circ}$. Double berms are designed at $25 \mathrm{~m}$ (weathered zone) and $50 \mathrm{~m}$ (fresh rock) vertical intervals. To date no bench-scale failure within the weathered zone in Main Pit has occurred. 


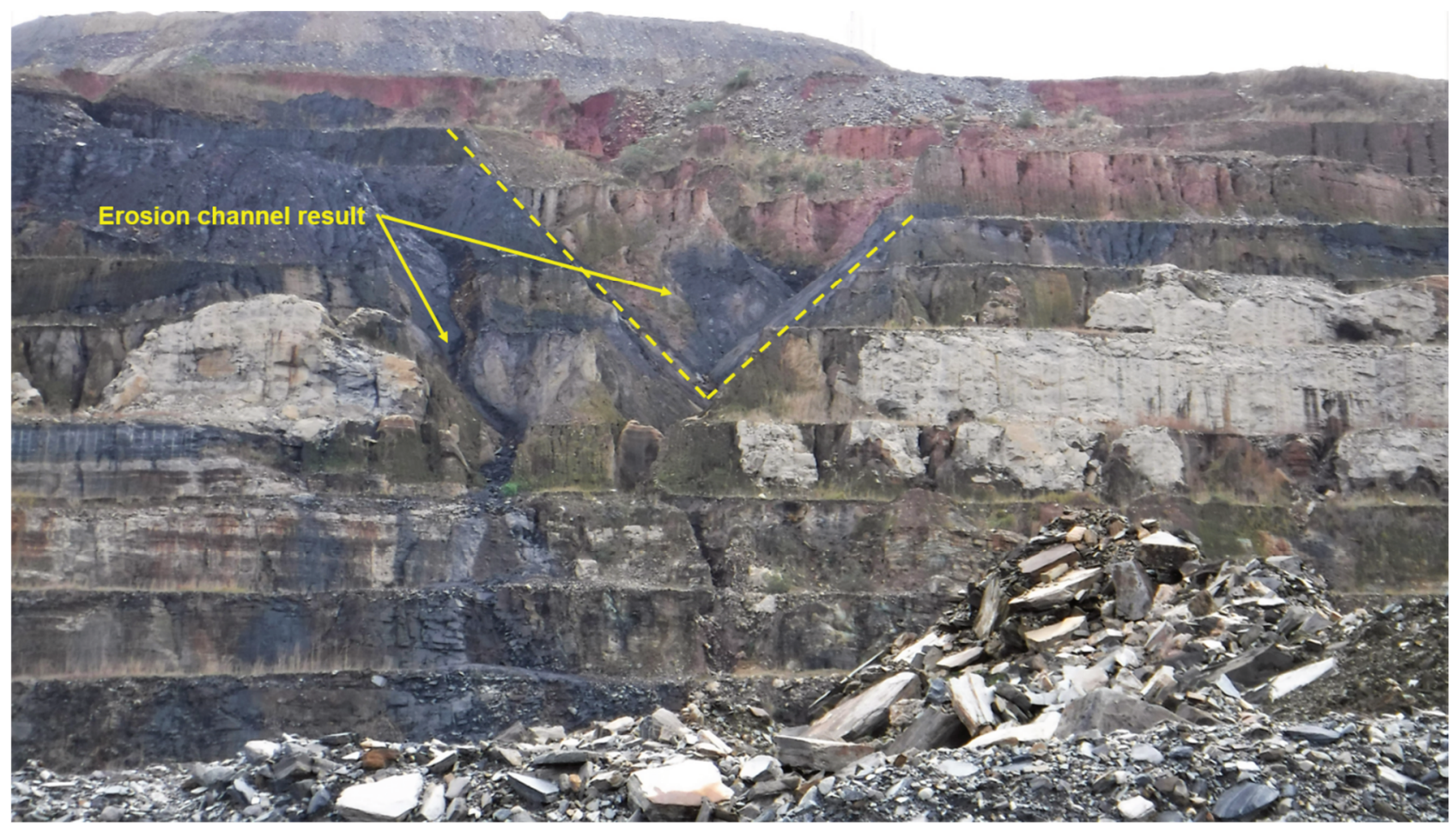

Figure 4 Erosion along relict structures in saprolite benches

Fairly weathered and unweathered (i.e. fresh rock) wall geometry includes $10 \mathrm{~m}$ high benches with $7 \mathrm{~m}$ wide catch berms and a bench face angle varying between $75^{\circ}$ to $80^{\circ}$. Approximately five benches have been excavated in fairly weathered material and three benches in fresh rock (Figure 5), and to date only localised instabilities, i.e. wedge or toppling, have occurred in these zones.

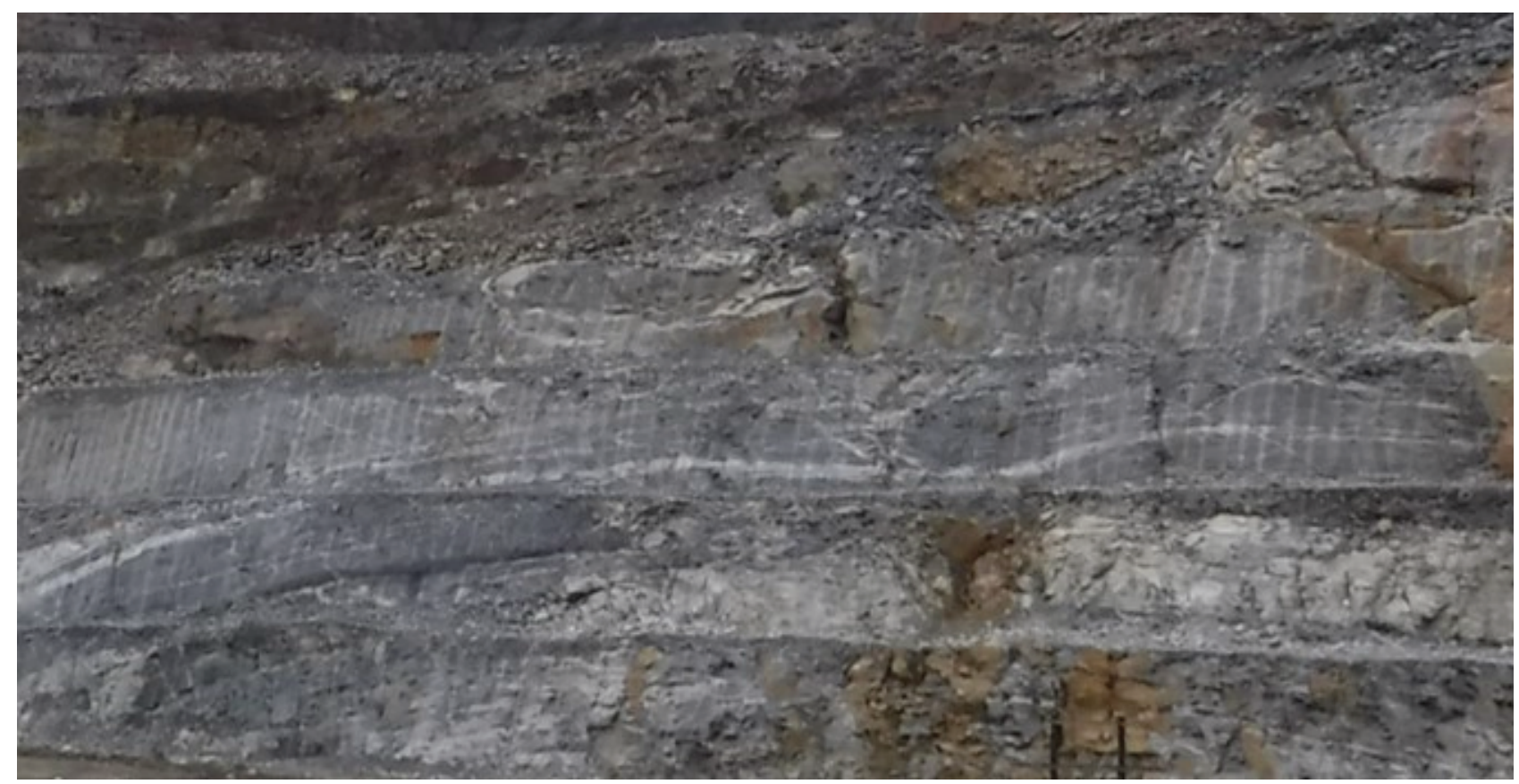

Figure 5 Ten metre high benches in phyllite

Failures within the transition zone (Figure 6) are generally associated with deeply weathered geologic structures. 


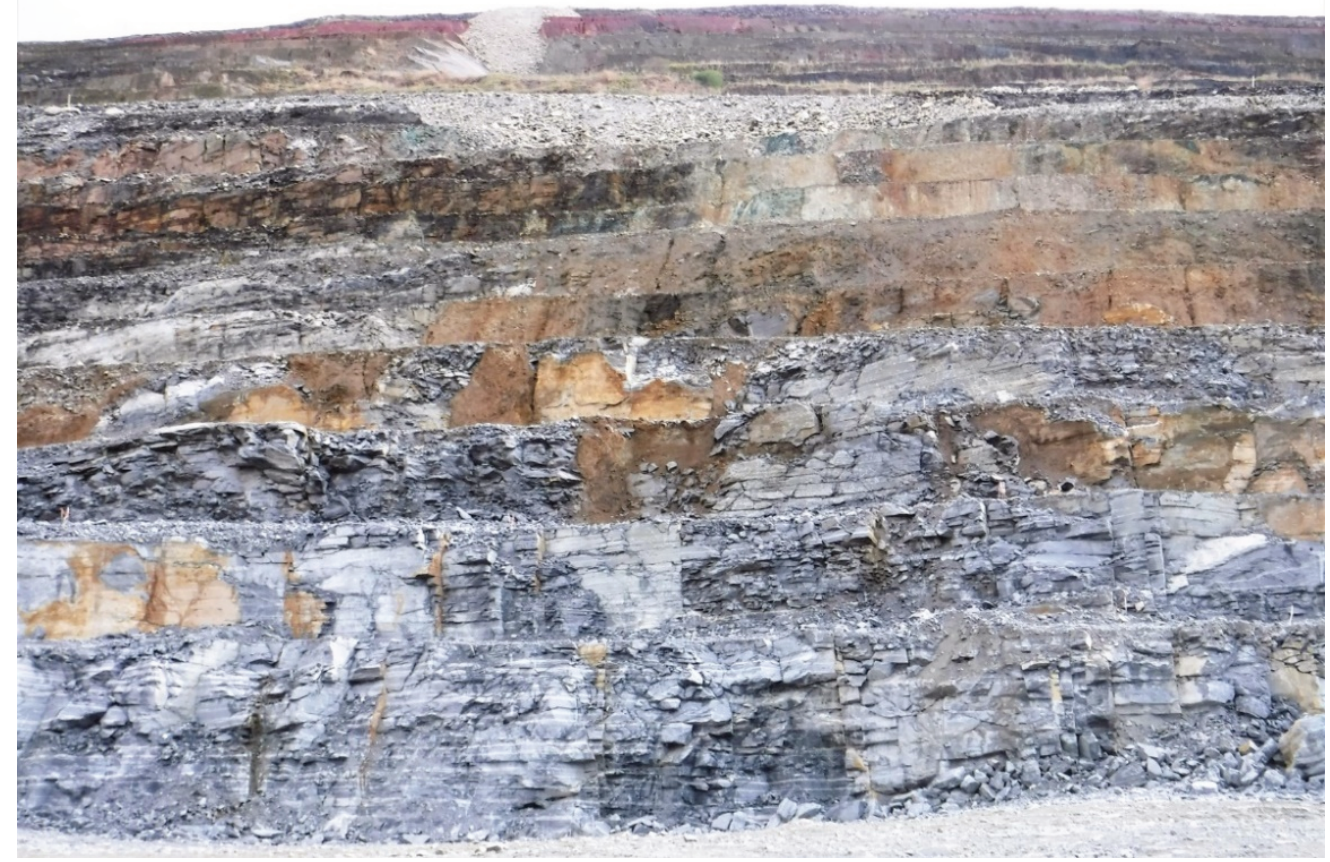

Figure 6 Benches in the transition zone between weathered and fresh marble

Two of the more notable failures that have occurred in Main Pit include failure of the Main 10 trolley-assist ramp and a large wedge failure in Main 12.

\subsection{Main 10 trolley-assist ramp failure}

Instability of Main 10 ramp was first identified during 2014, when the occurrence of sinkholes (varying in dimension from approximately $1.5 \mathrm{~m}$ diameter to $1.5 \mathrm{~m}$ deep to over $2 \mathrm{~m}$ diameter and $2 \mathrm{~m}$ deep) was noticed in line with the trolley-assist plinths on the highwall side. More sinkholes were observed during early 2015 (Figure 7). It was thought, despite it being the wet season, that the formation of these sinkholes was due to the presence of groundwater.

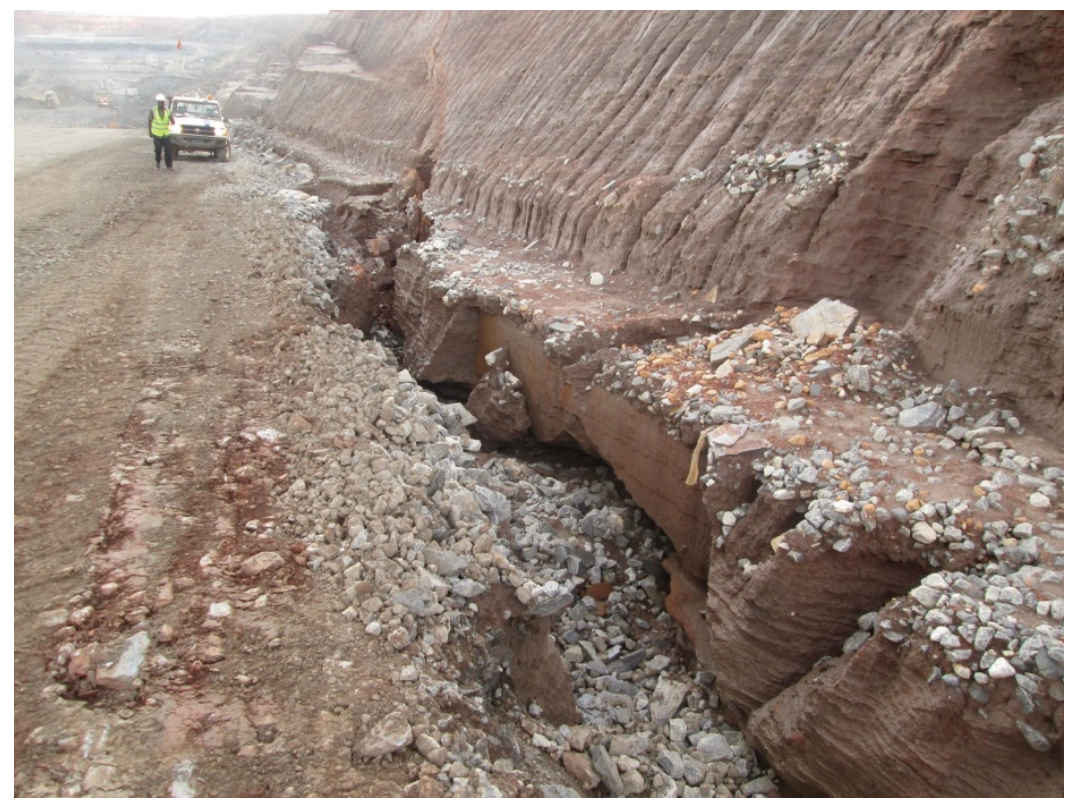

Figure 7 Sinkholes observed on Main 10 ramp during early 2015 
Around the same time that this sinkhole was observed (end of 2014 or beginning of 2015), sloughing of the saprolite benches beneath the ramp commenced; the initial failure was associated with steep-dipping foliation dipping into the pit and relict structures (Figure 8).

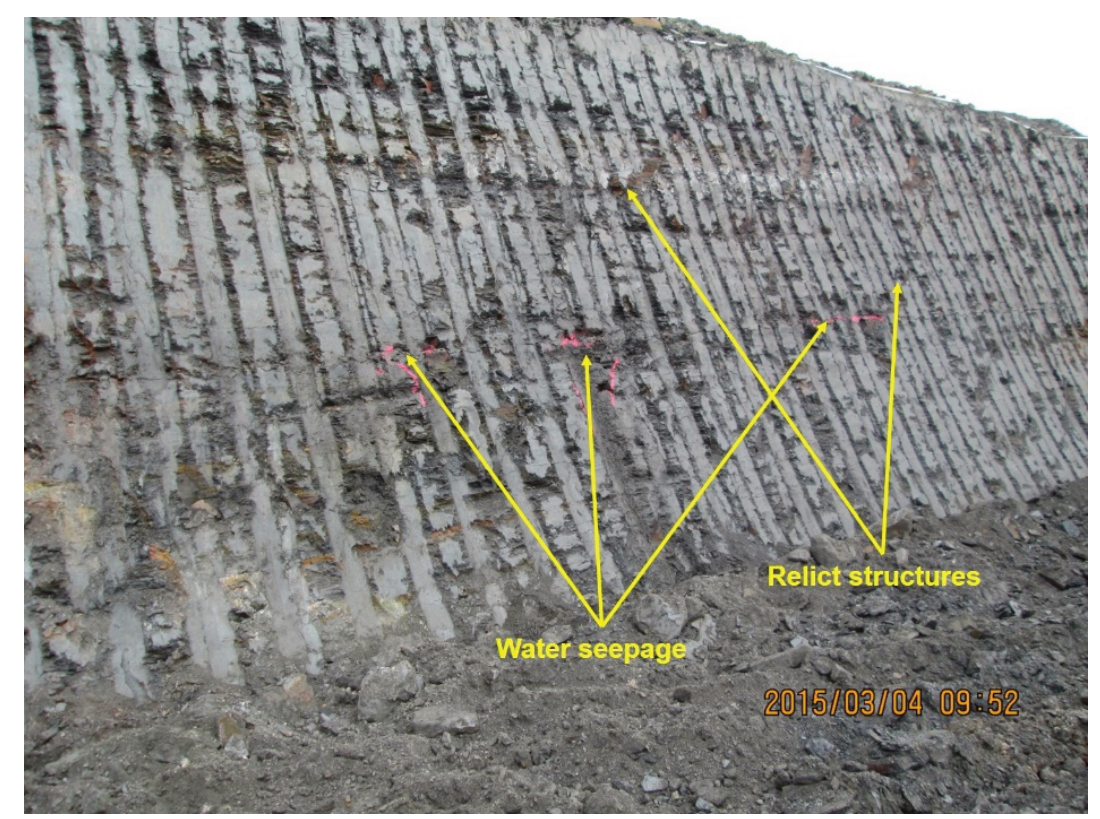

Figure 8 Cause of the onset of bench failure below the ramp

The recommendations at the time included construction of a windrow around the tension cracks that appeared on the ramp surface (Figure 9), and the installation of prisms on the windrow, which would be monitored to determine the rate of slumping.

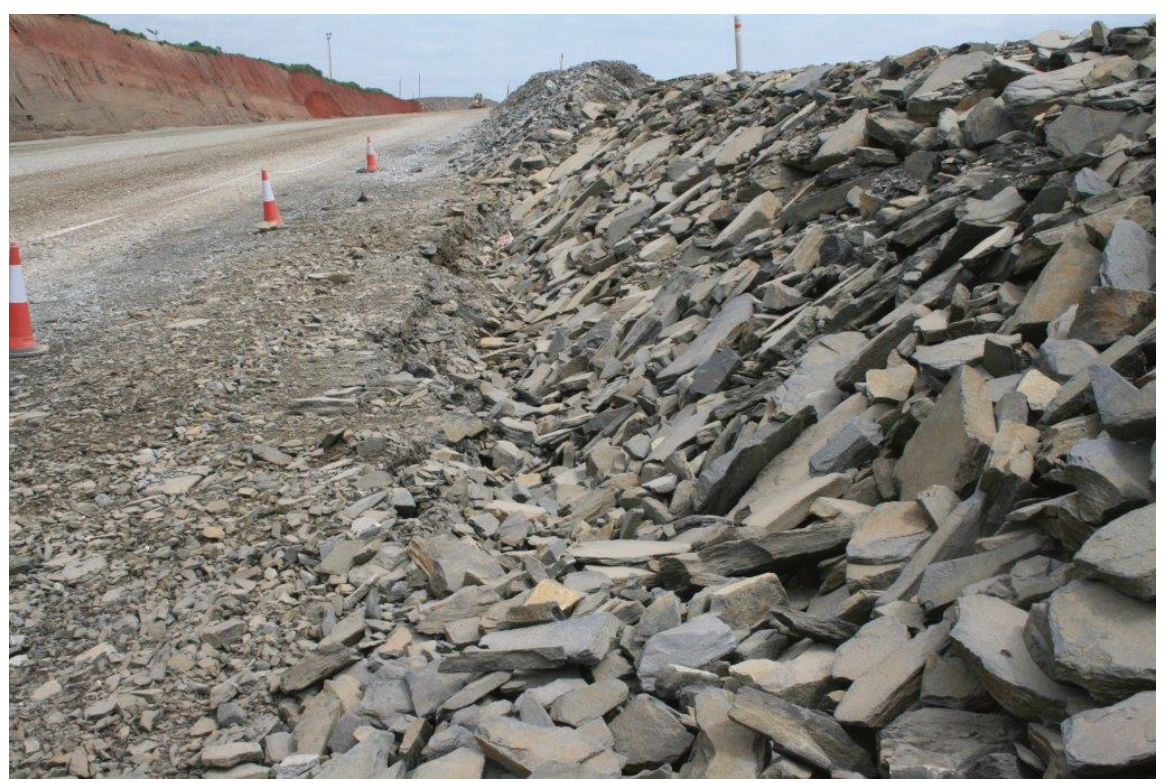

Figure 9 Slumping of the windrow on the M10 trolley ramp

Sometime between February 2015 and February 2016, six-metre long piles, comprising $150 \mathrm{~mm}$ internal diameter steel pipes filled with concrete) were installed on the ramp in an attempt to limit the extent of the tension cracks that formed on the ramp (Figure 10). 


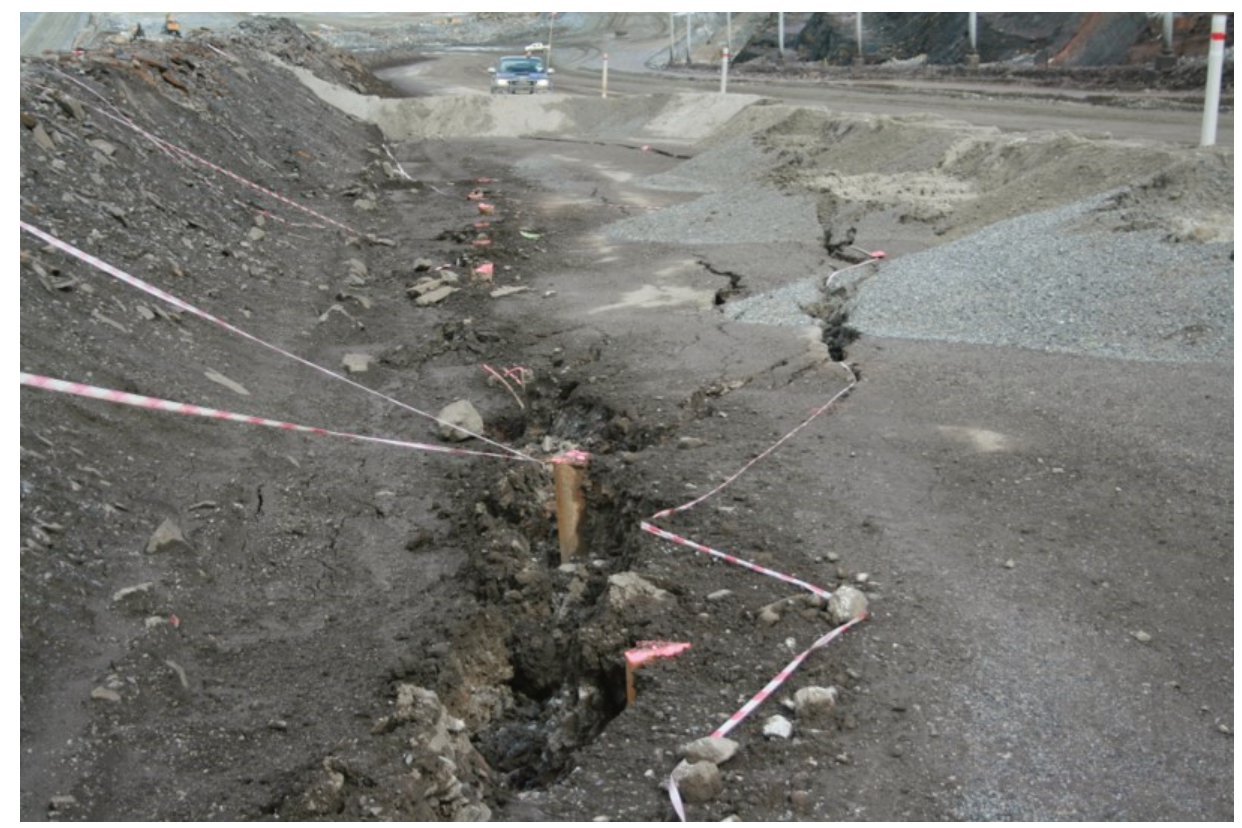

Figure 10 Six-metre long piles exposed along tension cracks on the ramp in February 2016

During early 2016, the tension cracks appeared once more on the ramp, this time extending beyond the initial (2015) failure. Because of the extent of the new failure zone; i.e. being further onto the ramp, a decision was taken on 2 April 2016 to install 18 nine-metre long piles $(150 \mathrm{~mm}$ diameter steel pipes filled with concrete), hoping that the additional three metre length would penetrate more competent ground below the failure plane; the depth of which was still undetermined. These piles were installed in the middle and behind the $6 \mathrm{~m}$ long piles.

Despite this remedial action, failure occurred again between December 2017 and March 2018 (Figure 11). Following the end of the wet season (April 2018), the affected portion of the ramp was rehabilitated, and a capping layer of compacted laterite was placed. This reduced the impact of instability during the November 2018 to March 2019 wet season; however, that did not prevent sloughing.

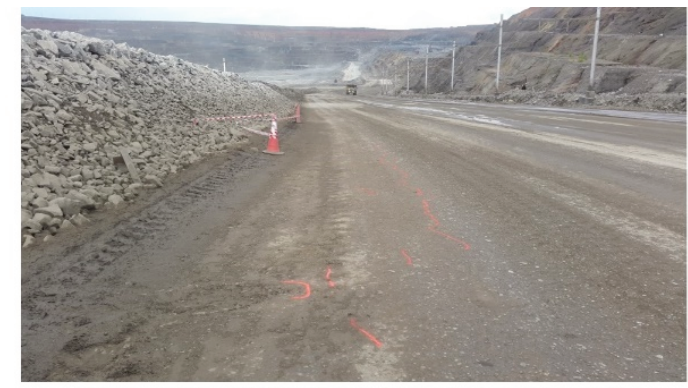

04 December 2017 (tension crack development)

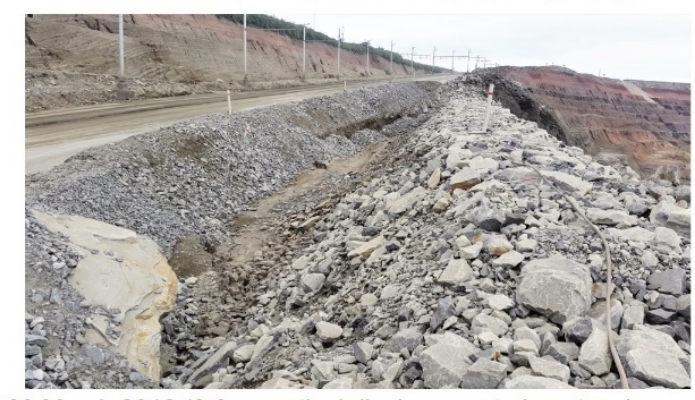

09 March 2018 (0.6 m vertical displacement along tension crack)

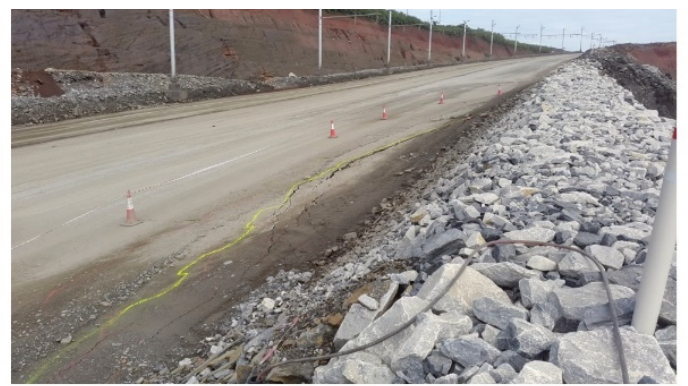

01 February 2018 (vertical displacement along tension crack)

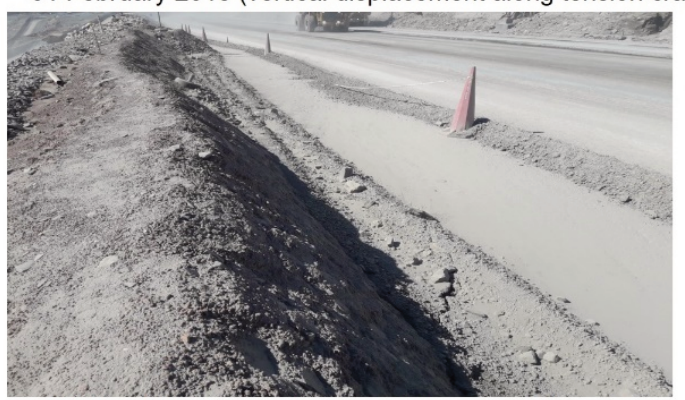

22 March 2019 (sloughing of windrow over the wall)

Figure 11 Failure of the open edge of the ramp during December 2017 and March 2018 


\subsubsection{Investigation into root cause of failure using a ground penetrating radar}

During August 2019, a ground penetrating radar (GPR) scan was conducted over the rehabilitated portion of the ramp in an attempt to determine the depth of the failure plane (Figure 12). From the scan, it was identified that the potential failure surface is possibly a foliation plane dipping towards the open edge of the ramp. The surface varies between $6.7 \mathrm{~m}$ in the middle of the ramp to $11.7 \mathrm{~m}$ at the open edge.
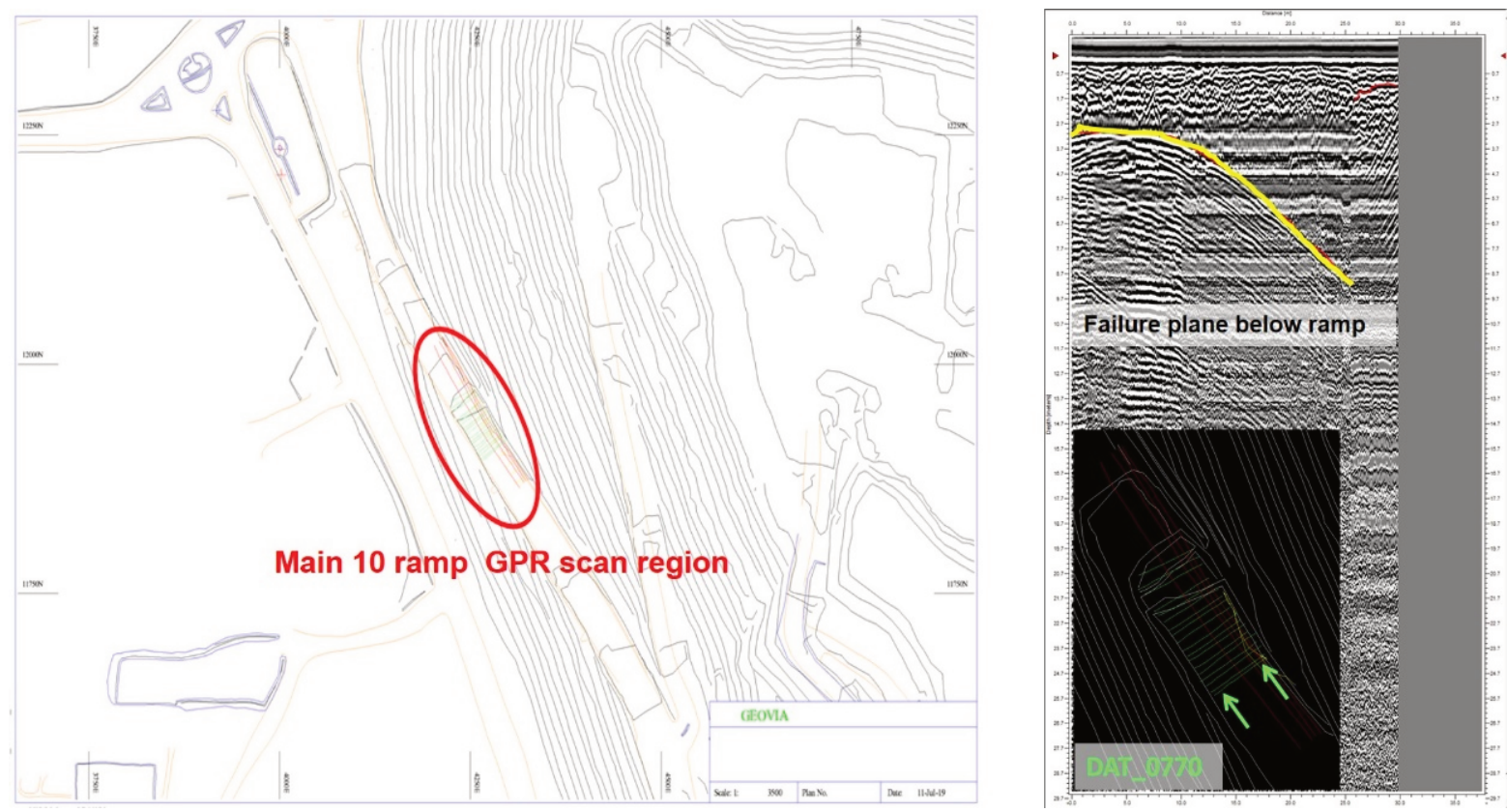

Figure 12 Ground penetrating radar (GPR) scan region and results

\subsubsection{Remediation}

A remediation plan (Figure 13) was developed, which includes diverting groundwater away from the failure surface in the rehabilitated portion of the ramp and will be implemented during the 2020 dry season.

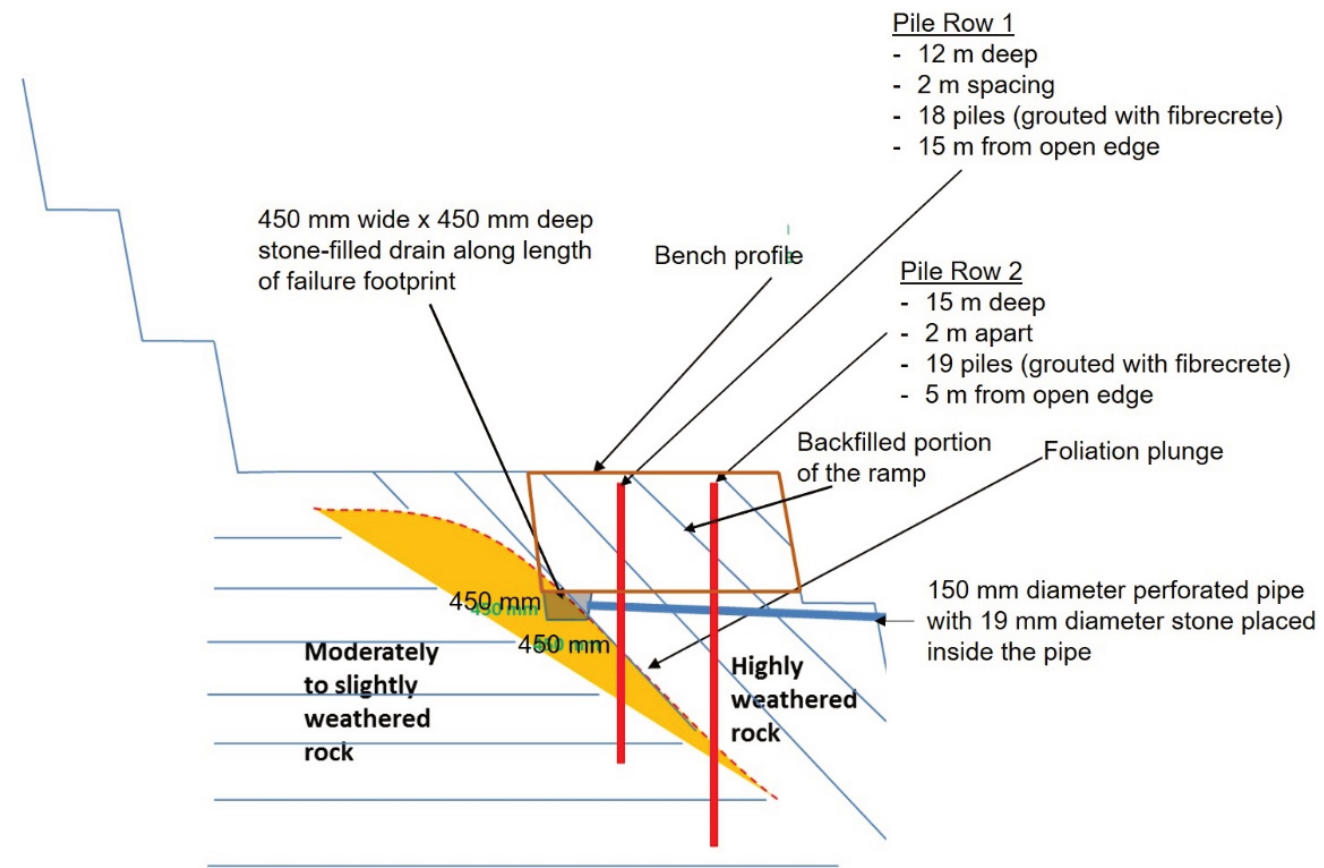

Figure 13 Section through the planned sub-surface drainage to manage groundwater along the foliation 


\subsection{Main 12 wedge failure}

In November 2015, an approximately $600 \mathrm{~m}^{3}$ wedge failure incorporating 14 five metre high benches occurred in the saprolite in Main 12. The first signs of instability in this portion of the wall were observed during April 2015, and over the following months the instability was observed in lower benches (Figure 14). The failed material was initially contained on the catch berms of the benches below the failure.

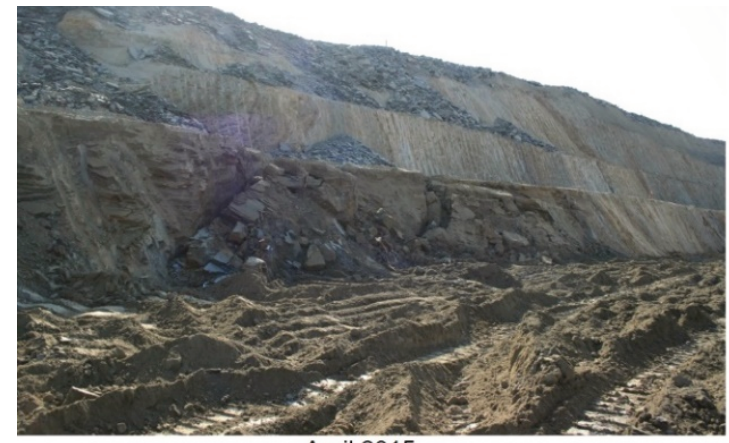

April 2015

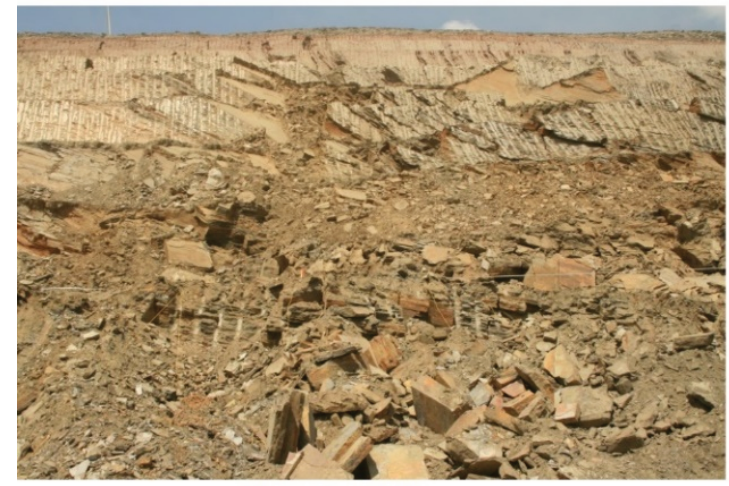

November 2015

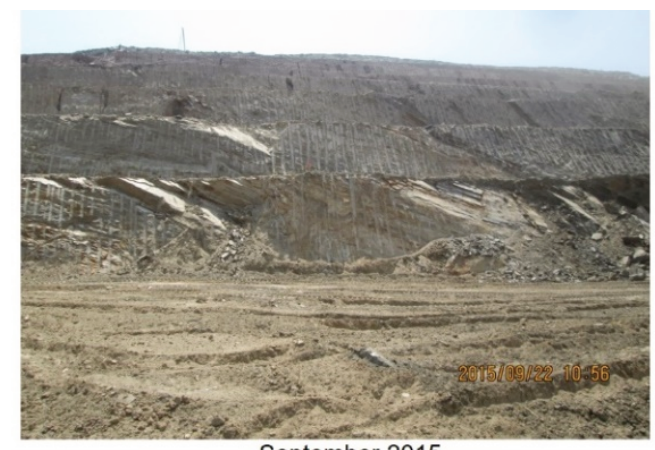

September 2015

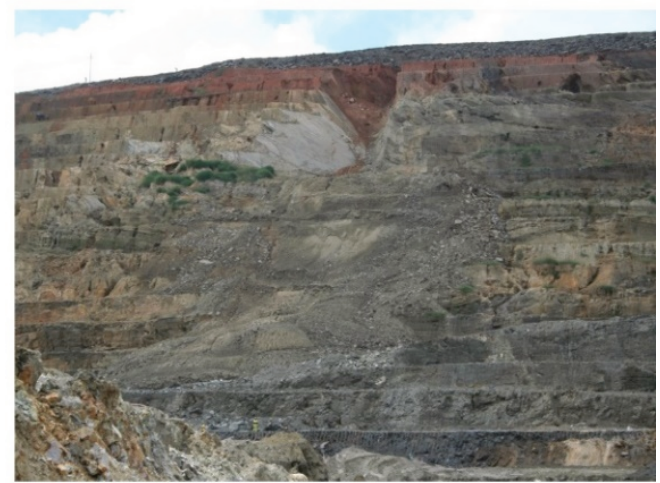

Final failure volume

\section{Figure 14 Progression of wedge failure in Main 12}

The wedge was formed by the intersection of the steep-dipping foliation around a gabbro intrusion and an approximately $85^{\circ}$ dipping joint (Figure 15). The intersection of these two geologic structures daylighted out of the slope. Therefore, no further failure on the downdip side of the wedge is expected.

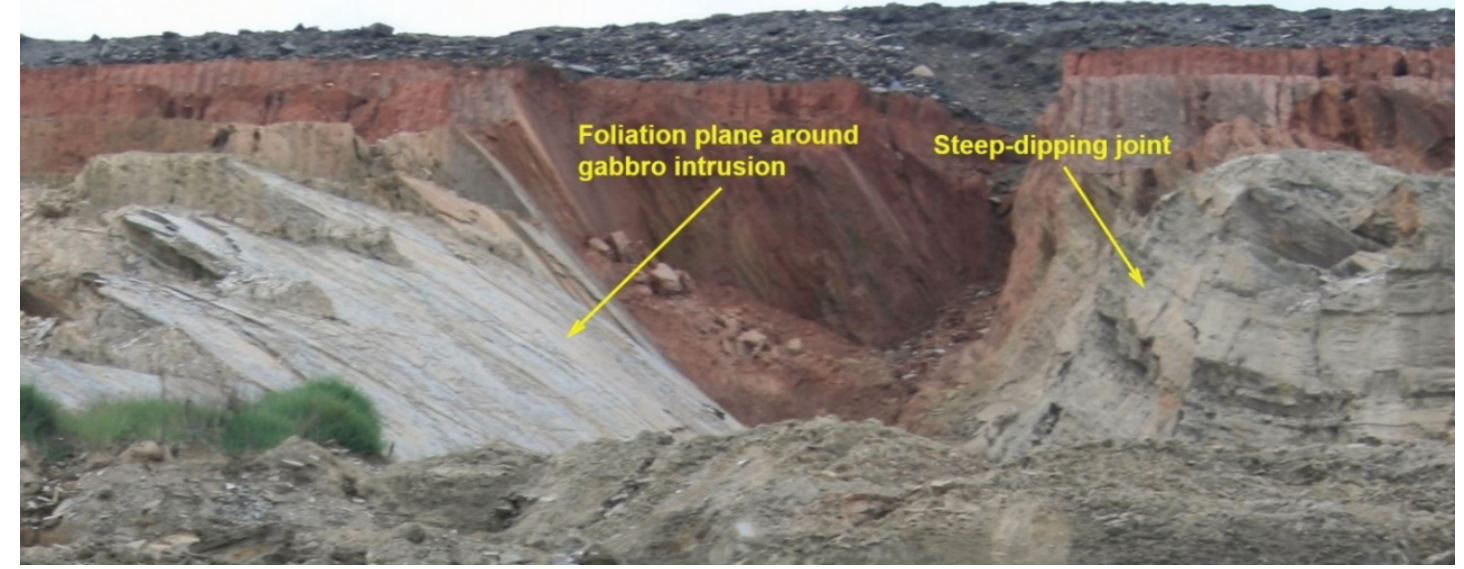

\section{Figure 15 Boundaries of Main 12 wedge}

Failure of the scarp continued through until December 2017 (Figure 16), with the potential of the failure continuing onto the Main 12 trolley-assist ramp. 


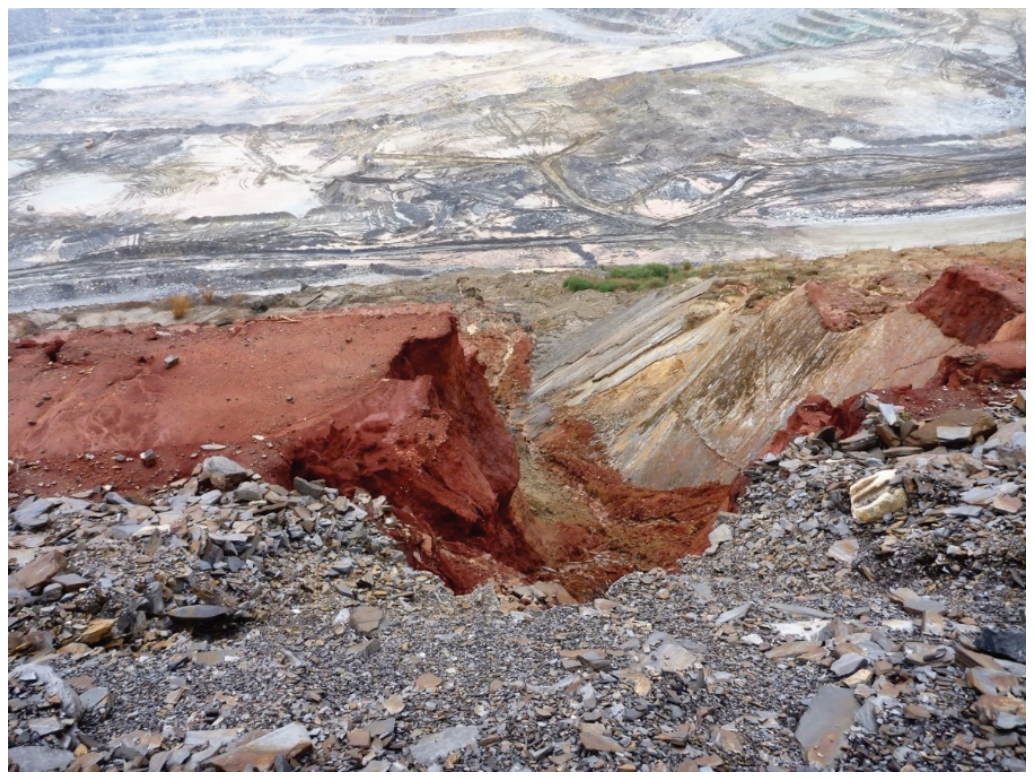

Figure 16 Continued sloughing of saprolite from the scarp of the wedge failure

It was hypothesised that the source of the water saturating the saprolite was from the waste rock dump to the north of this section of the pit. Two 15-metre deep dewatering investigation holes were drilled along the northern shoulder of the ramp to identify whether water was indeed flowing from the waste rock dump, beneath the ramp foundation towards the pit. The investigation revealed that water was indeed flowing from the north towards the pit.

\subsubsection{Remediation}

A remediation plan was developed which included initially removing some of the sloughed material at the base of the failure during the dry season, constructing a rock buttress at the toe of the failure, and placing waste rock into the failure footprint from the ramp (Figure 17).

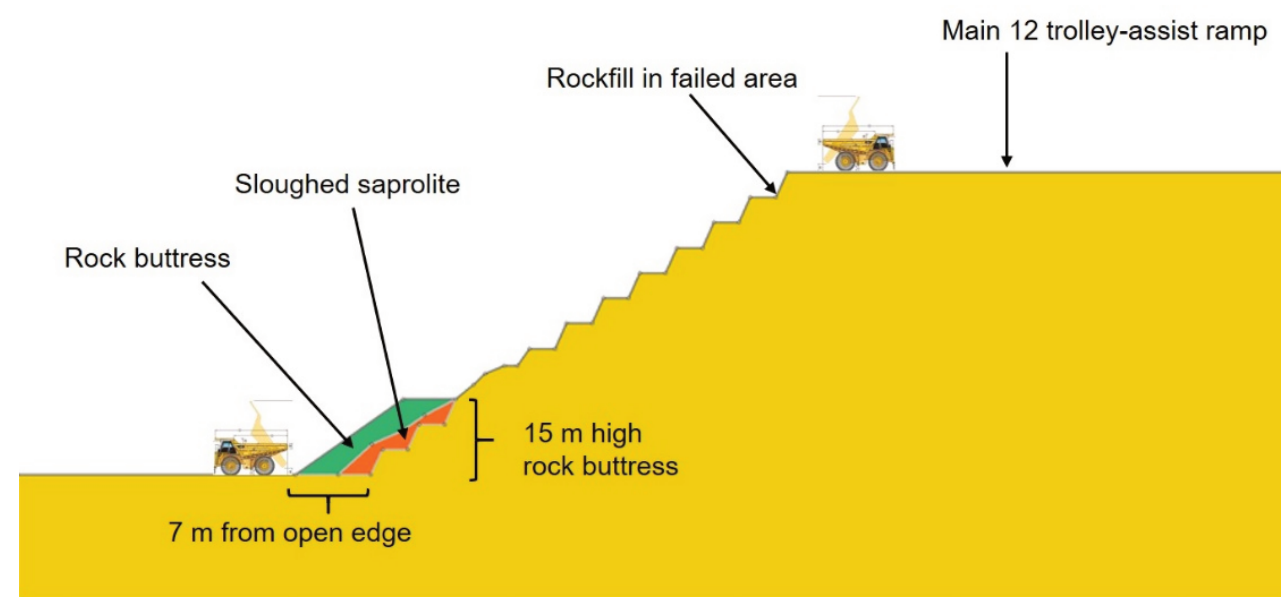

Figure 17 Schematic of remediation plan for Main 12 wedge failure

The placement of the waste rock was to minimise the potential for the scarp to fail into the ramp (Figure 18). The surface water management plan was then revisited to ensure that drains at the base of this waste rock dump were lined with compacted laterite and graded to facilitate water drainage towards the northeast. 


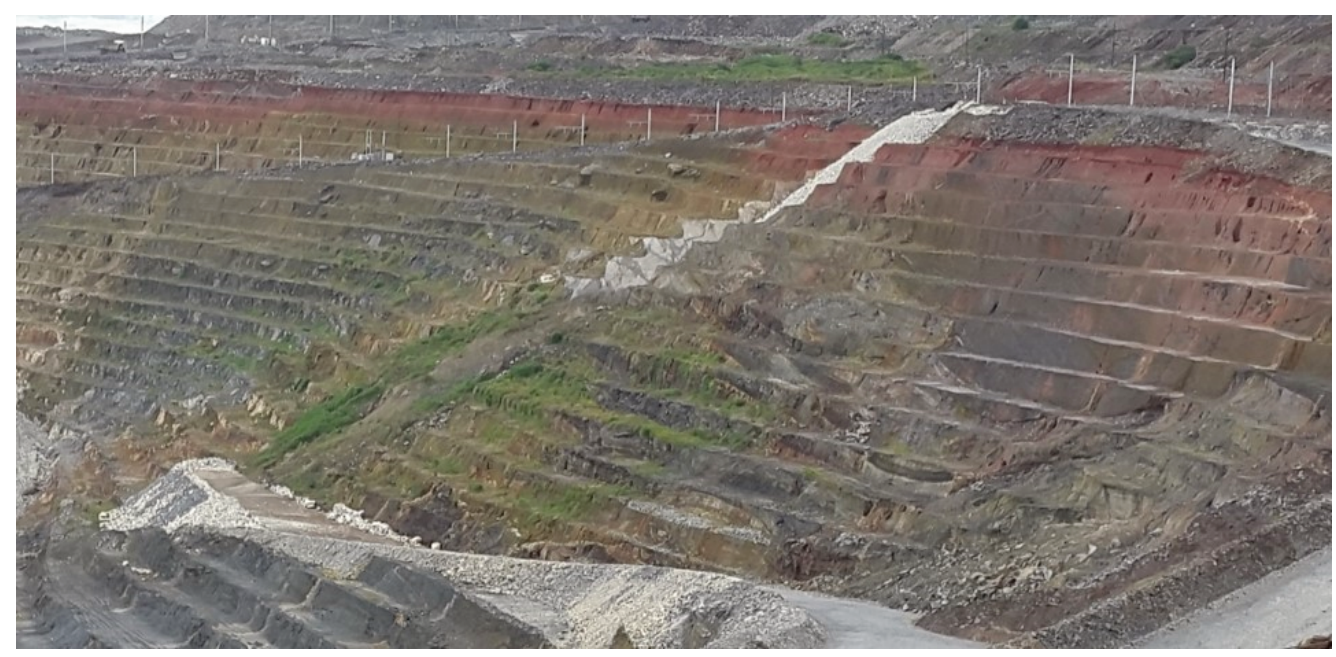

Figure 18 Backfilled wedge failure footprint and constructed abutment

Since the completion of this remedial action, no further instability has been experienced in this specific portion of Main 12.

\section{$4 \quad$ Challenges facing wall stability}

Two issues that are still being faced regarding wall stability include the effect of continuous weathering of exposed benches and the effect of presplit blasting on bench stability.

\subsection{Effect of continued weathering}

Host material comprising the wall at Kansanshi Mine includes phyllite, schist, marble (limestone) and gabbro. There is variation of minerals within the material, particularly within the schist (which weathers down to silty clay) and phyllite (which weathers down to a clayey silt). It appears that when the initial and subsequent wall geometries were designed, the mineral composition was not taken into consideration, particularly in the phyllite. Unfortunately, the effect of environmental conditions on the exposed material on the wall was generally not considered when designing the wall geometry.

Evidence of this is resulting in instability of a specific portion of Main 12 North-East wall (Figure 19).

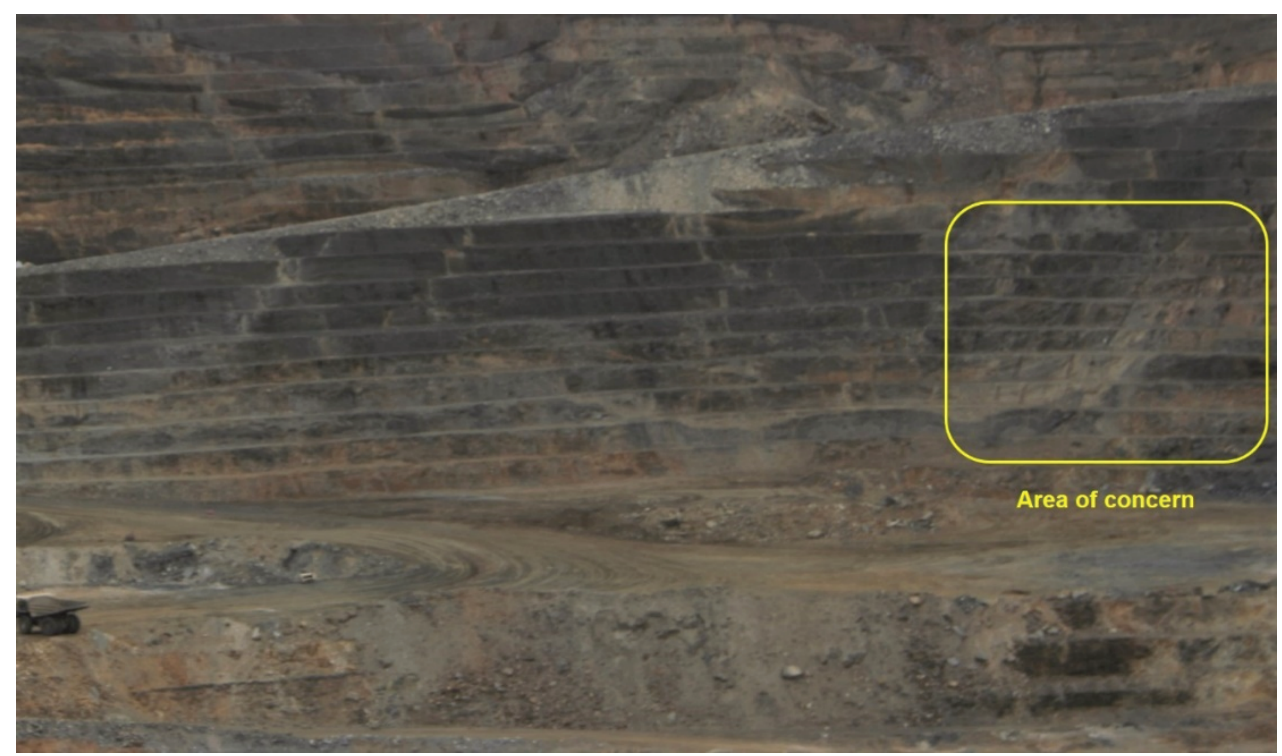

Figure 19 Continued weathering of exposed walls in Main 12 North-East (November 2017) 
This specific portion of the pit was mined approximately five years ago, and what was initially assumed to be stable fairly weathered phyllite benches, has now deteriorated to unstable saprolite benches (Figure 20).

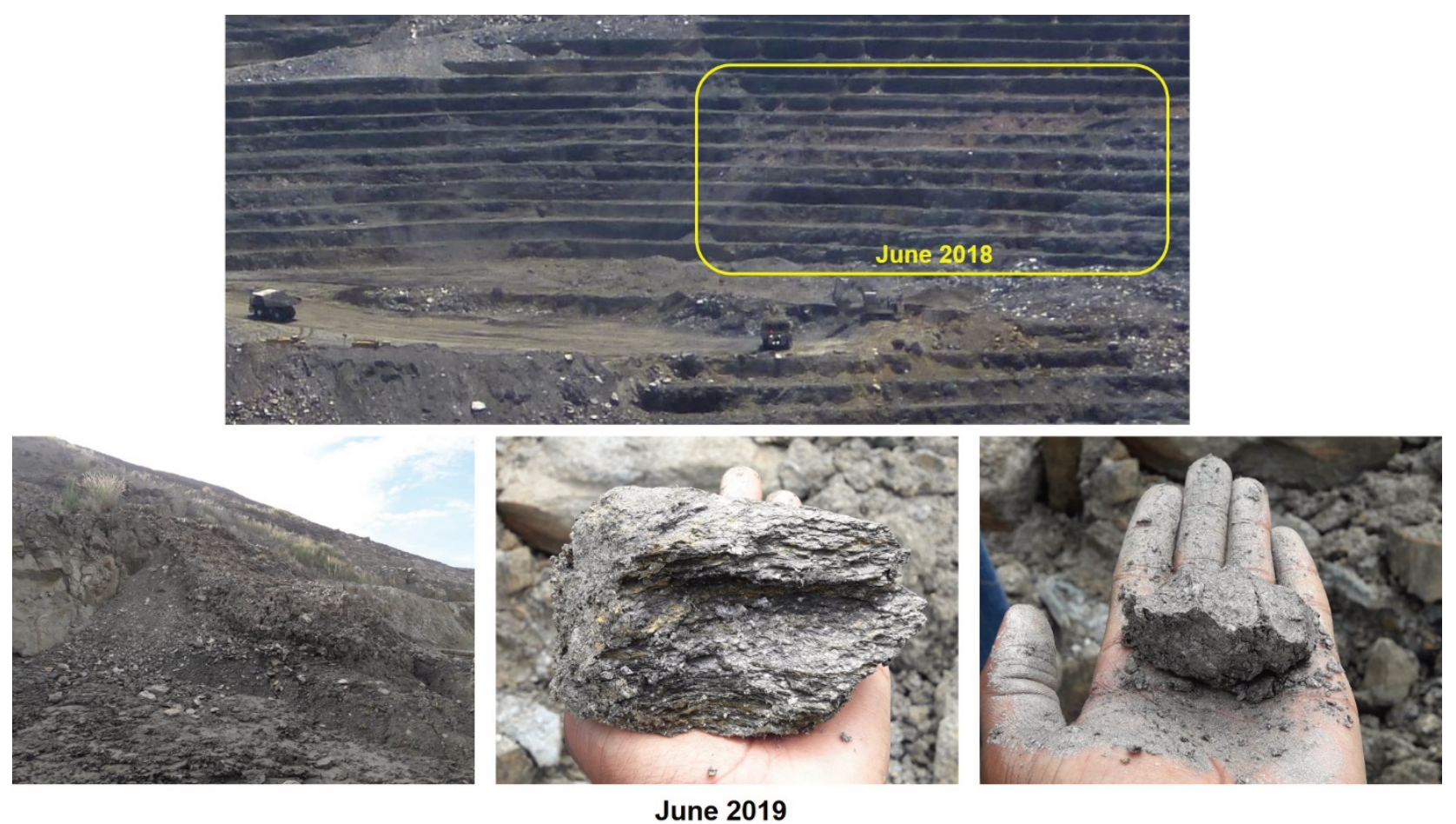

Figure 20 Degradation of the phyllite benches in Main 12 North-East

\subsection{Presplit blasting}

Presplitting has not been successful as a result of variability of the material comprising the pit wall. Completed presplit blasting has not been encouraging, due to recorded blast damages or back-break in the transition zone between the weathered and unweathered units (Figure 21). This has resulted in localised bench-scale failures. A review of material boundary within the transitional zone is being defined to delineate suitable layers to enhanced presplit and other appropriate wall control blasting to minimise blast-induced damages.
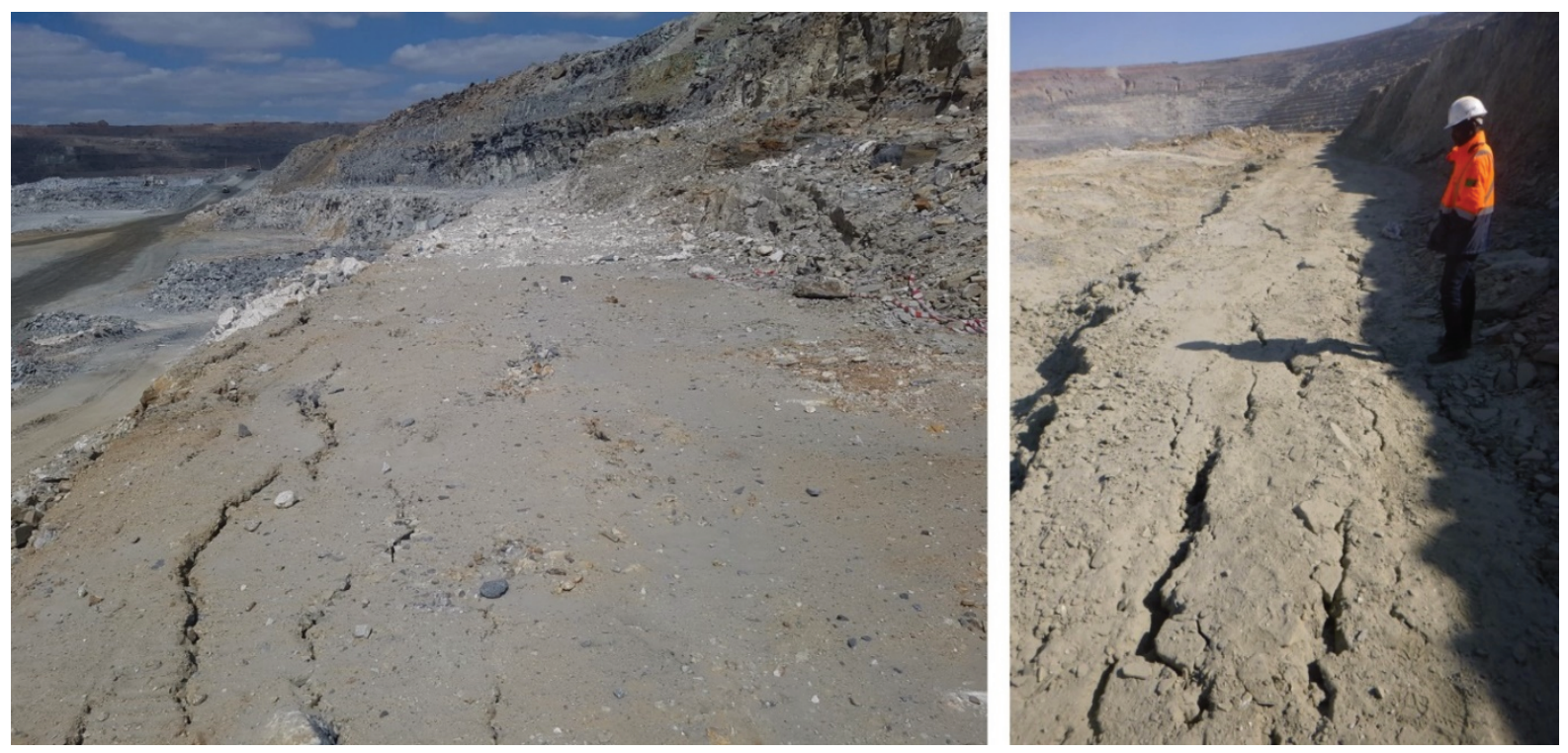

Figure 21 Examples of overbreak from the presplit blast 


\subsection{Groundwater management}

Historically very little was done to develop an understanding of groundwater on the mine, and slope design assumed that the walls were dry. However, over the past couple of years, attention is being paid to determine the source and direction of groundwater flow, as it is impacting on the dewatering of the Main Pit floor particularly during the wet season, and drilling in West 2 of North West Pit (Figure 22).

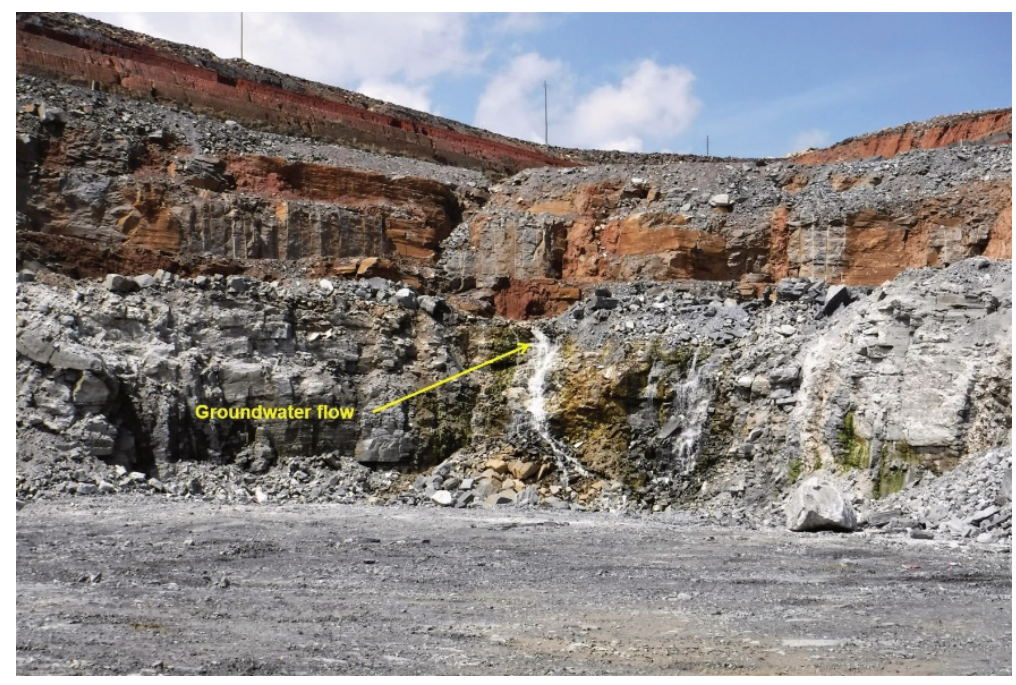

Figure 22 Groundwater flow in the western corner of North West Pit

\section{Conclusion}

Two fairly large-scale failures have occurred in Main Pit, both in weathered material and associated with geologic structure. In both instances, no attempt was made to identify the root cause of the failure, assuming that they were purely geologic structure-driven. However, progressive failure continued to occur over a couple of years, with the solution being either reconstructing the Main 10 ramp failure surface every dry season, and acceptance of the continued sloughing of the failure boundaries in Main 12. Once an effort was made to understand the root cause of the failures, in both instances it was identified that water had driven the initial failures. An attempt was then made to identify the source of the water and, once identified, how best to manage it. Practical solutions were developed to address these instabilities, and the one implemented for Main 12 (i.e. the construction of a buttress and backfilling the failure surface to the scarp) appears to have been successful. The proposed sub-surface drainage for Main 10 trolley-assist ramp has yet to be approved.

A number of legacy issues pertaining to slope performance are beginning to materialise, particularly the effect of exposure of the northeastern phyllite benches in Main 12. The phyllite, which is being exposed to both groundwater and surface water runoff, has started to weather from a saprock to a saprolite, and this has started to creep. Fortunately, there is a ramp a couple of benches below this material, and therefore containment capacity to prevent the failed material from creeping onto the benches below the ramp. Unfortunately, this is a final wall, and there is no opportunity to push this wall back to a shallower angle.

A dewatering and depressurisation (of the saprolite) program has been developed and will commence in January 2020. This program has been specifically developed for Main Pit, and the vertical dewatering holes are planned to be fitted with vibrating wire piezometers and small pumps (on alternate holes). The horizontal depressurisation holes are planned to be drilled to a depth of $100 \mathrm{~m}$ and spaced $50 \mathrm{~m}$ apart in specific cutbacks.

Presplit blast design in the transition zone is being reviewed. It has been realised that the 'normal' presplit design used in fresh rock should not be used in transition zones. A programme is being developed where the Blast Engineer first walks the block where the blast is to be designed, and then designs the blast specific to the block, taking the various material competencies and mechanical properties into account. 